\title{
Synergistic Dielectric and Semiconducting Properties in Fluorescein Monopotassium Salt \\ Random Copolymers
}

Zhongqiang Zhao ${ }^{\mathrm{a}, \mathrm{b}}$, Zhongbo Zhang ${ }^{\mathrm{b}}$, Sandra Pejić ${ }^{\mathrm{c}}$, Guoqiang Zhang ${ }^{\mathrm{b}}$, Yufeng Zhu ${ }^{\mathrm{b}}$, Hewen Liu $^{\mathrm{a}, *}$, Morton Litt ${ }^{\mathrm{b}}$, Genevieve Sauve ${ }^{\mathrm{c}, *}$, and Lei Zhu ${ }^{\mathrm{b}, \mathrm{c}^{*}}$

${ }^{a}$ Key Laboratory of Soft Matter Chemistry, Chinese Academy of Sciences and Department of Polymer Science and Engineering, University of Science and Technology of China, 96 Jinzhai Road, Hefei, Anhui Province 230026, P. R. China

${ }^{\mathrm{b}}$ Department of Macromolecular Science and Engineering, Case Western Reserve University, Cleveland, Ohio 44106-7202, United States

${ }^{\mathrm{c}}$ Department of Chemistry, Case Western Reserve University, Cleveland, Ohio, 44106-7078, United States

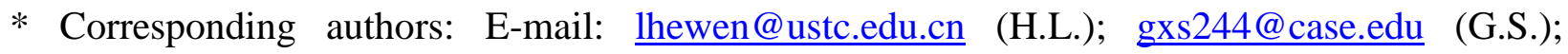
1xz121@ case.edu (L.Z.). 
ABSTRACT: The low dielectric constant $\left(\varepsilon_{\mathrm{r}} \sim 3-4\right)$ for semiconducting polymers has been a major cause for their poor performance compared with the inorganic semiconductors, which possess high dielectric constants above 10. This study aimed to increase the electronic/atomic dielectric constant at high frequencies (i.e., $\varepsilon_{\mathrm{r} \infty}$ ) for semiconducting polymers. A new design strategy was proposed based on the electric field-induced tautomeric structures in conjugated fluorescein. To achieve this goal, fluorescein monopotassium salt-containing random copolymers were synthesized with 50 and 75 mol.\% functionality. To reduce the strong electrostatic attraction between the $\mathrm{K}^{+}$cation and the phenolate anion, 18-crown- 6 ether was complexed with $\mathrm{K}^{+}$in the fluorescein copolymers. A relatively high $\varepsilon_{\mathrm{r} \infty}$ of $\sim 5.5$ and high electron mobility of $0.153 \mathrm{~cm}^{2} /(\mathrm{V} \cdot \mathrm{s})$ were achieved for the $75 \mathrm{~mol} \%$ fluorescein $\mathrm{K}^{+} / 18 \mathrm{C} 6$ copolymer. The high electron mobility could be attributed to the relatively high static dielectric constant $\left(\varepsilon_{\mathrm{rs}} \sim 9\right.$ at $\left.1 \mathrm{~Hz}\right)$ of the sample. The fluorescein monopotassium salt copolymers behaved as $n$-type semiconductors with an optical band gap around $2.26 \mathrm{eV}$.

Keywords: Semiconducting polymers, dielectric constant, fluorescein monopotassium salt, charge carrier mobility, optical band gap 


\section{Introduction}

Polymeric semiconductors have drawn much attention in research because of their promise to enable inexpensive, flexible, lightweight, and scalable organic electronic devices, such as organic photovoltaics (OPVs), photodetectors, field-effect transistors, and organic light-emitting diodes.[1, 2] However, typical dielectric constants $\left(\varepsilon_{\mathrm{r}}\right)$ for semiconducting polymers are fairly low $\left(\varepsilon_{\mathrm{r}} \sim 3-4\right)$, in contrast with crystalline silicon, $\varepsilon_{\mathrm{r}}=11.7$ [3] and semiconducting perovskites, $\varepsilon_{\mathrm{r}}=28$.[4] The low $\varepsilon_{\mathrm{r}}$ has a negative impact for OPV and photodetector applications. For example, excitons in semiconducting polymers have a large binding energy of $0.3-1.0 \mathrm{eV}$, which is currently overcome by using a heterojunction between two organic semiconductors (a donor and an acceptor) having an appropriate energy offset.[5] This reduces the available electrochemical potential energy, thus limiting open circuit voltages $\left(\mathrm{V}_{\mathrm{oc}}\right)$ and the power conversion efficiency (PCE). Furthermore, the strong Coulombic attractions promote charge recombination, limiting free charge carrier generation, transport and collection. These further lower the PCE and the optimal film thickness in OPVs.

The permittivity of a dielectric material relates to how easily charges can be separated (or polarized) in the bulk.[6] The higher the $\varepsilon_{\mathrm{r}}$, the easier the charges can be polarized. The separated charges can greatly increase the local electric field due to the applied field-induced long-range dipole-dipole interactions.[7] As a result, a high $\varepsilon_{\mathrm{r}}$ favors easy charge carrier formation (i.e., exciton dissociation) and charge carrier mobility in semiconducting polymers. According to theoretical calculations, high exciton dissociation energy and charge carrier 
recombination issues can be overcome by increasing the $\varepsilon_{\mathrm{r}}$ of the active layer to $\sim 9,[8]$ which would give exciton binding energy on the order of $\mathrm{k}_{\mathrm{B}} \mathrm{T}\left(\mathrm{k}_{\mathrm{B}}\right.$ is Boltzmann constant and $\mathrm{T}$ is absolute temperature) and efficiencies greater than 20\%. A perspective by Camaioni and Po nicely argues for the need to design active materials with higher $\varepsilon_{\mathrm{r}}$, because they are predicted to have efficiencies comparable to inorganic semiconductors while keeping the advantages of low production cost, large area and flexible devices by using organic materials.[9]

To enhance the $\varepsilon_{\mathrm{r}}$ for polymers, one needs to increase the dipole density $(\mathrm{N})$, polarizability $(\alpha)$, and/or local electric field $\left(\mathrm{E}_{\mathrm{L}}\right)$, because the macroscopic $\varepsilon_{\mathrm{r}}$ is closely related to these microscopic quantities via polarization $(\mathrm{P}):[10]$

$$
\left(\varepsilon_{r}-1\right) \varepsilon_{0} E_{0}=P=N \alpha E_{L}
$$

where $\varepsilon_{0}$ is vacuum permittivity and $\mathrm{E}_{0}$ is the electric field applied to the dielectric material. Strategies of mesoscale blending and microscopic incorporation of highly dipolar groups in the polymer chains have been proposed to enhance the $\mathrm{E}_{\mathrm{L}}$ and thus the $\varepsilon_{\mathrm{r}}$ for semiconducting polymers. Note that doping of semiconducting polymers should be avoided, because highly doped semiconducting polymers are conducting by nature (i.e., band gap $=0$ ), even though their apparent $\varepsilon_{\mathrm{r}}$ are reported to be thousands (note that the $\varepsilon_{\mathrm{r}}$ for conductive metals is $\infty$ ).[11] Blending of polar or high $\varepsilon_{\mathrm{r}}$ additives into semiconducting polymers may increase the overall permittivity. The key is to increase the $\mathrm{E}_{\mathrm{L}}$ in the bulk of the semiconducting polymers. For example, introducing high $\varepsilon_{\mathrm{r}}$ inorganic nanoparticles and poly(vinylidene fluoride) (PVDF)-based nanostructures has demonstrated enhanced performance for organic solar cells.[5, 
12-15] Macroscopic phase separation at the micron length scales should be avoided to keep the effectiveness of local field enhancement. Even for compatible conjugated polymer blends, the increase of $\varepsilon_{\mathrm{r}}$ is usually limited by the amount that can be blended before macrophase separation.[16]

The effect of microscopic incorporation of dipolar groups in bulk semiconducting polymers can be further divided into two frequency regimes, i.e., $\mathrm{MHz}$ and $>\mathrm{GHz}$ ranges. To enhance the $\varepsilon_{\mathrm{r}}$ in the $\mathrm{MHz}$ range, switchable permanent dipolar groups can be attached to the polymer chains. Hummelen and coworkers showed that functionalization of fullerenes and conjugated polymers with chains of two or three ethylene glycol repeating units increase the overall $\varepsilon_{\mathrm{r}}$ to $\sim 6 .[17,18]$ They demonstrated that functionalization did not negatively affect charge carrier mobility or introduce trap states. Conjugated polymers with zwitterions in their side chains have been synthesized and used as interlayers in organic optoelectronic devices.[19-21] Liu et al. introduced a redox inactive salt to a conjugated polymer designed to incorporate ions,[22] and demonstrated that this suppressed charge recombination on the $\mu$ s time scale. Cho et al. showed that $-\mathrm{CH}_{2} \mathrm{CN}$ groups in the side-chains of conjugated polymers increased the $\varepsilon_{\mathrm{r}}$ from $\sim 3.5$ to $\sim 5.0$ and suppressed bimolecular recombination losses in bilayer devices.[23] Yang et al. showed that fluorine substituents on a conjugated polymer backbone increased the $\varepsilon_{\mathrm{r}}$, lowered the binding energy of charge transfer excitons, and slightly increased $\mathrm{V}_{\mathrm{oc}}$, in addition to other benefits from using fluorine substituents.[24] A theoretical study by de Gier et al. showed that introducing dipoles in the side-chain of conjugated polymers could 
stabilize the charge transfer states, thus decreasing or eliminating the charge transfer binding energy.[25] They argued that incorporating high dipole moment groups could help all fields, where generating free charges from excitons is a central problem, as long as the group dipole moments were sufficiently large and able to rotate.

Scheme 1. A proposed mechanism to enhance electronic polarization in a semiconducting polymer containing fluorescein monopotassium salts. The electric field-induced Keto-enol tautomerism can generate a large dipole moment and thus increase electronic polarization. The $\mathrm{K}^{+}$can be either alone or complexed with 18-crown-6.

Nonetheless, the lifetime of excitons is on the order of nanoseconds and the time for charge separation is even shorter.[1, 2] In general, permanent dipolar groups will not be able to rotate above $\sim 10 \mathrm{GHz}$ (e.g., the relaxation peak for water at room temperature is at $20 \mathrm{GHz}$ [26]). As a result, both $\varepsilon_{\mathrm{r}}$ and $\mathrm{E}_{\mathrm{L}}$ will be decreased. In order to enhance the $\varepsilon_{\mathrm{r}}$ above the $\mathrm{GHz}$ range (i.e., $\varepsilon_{\mathrm{r} \infty}$ ) and the electronic polarization must be used (note that the atomic/vibrational polarization for polymers is usually $10-30 \%$ of the electronic polarization [10, 27]). Semiconducting regioregular poly(3-hexylthiophene) (P3HT) has an $\varepsilon_{\text {roo }}$ of $~ 3.6,[28]$ primarily owing to the polarization of delocalized electrons in the conjugated main chain. One would argue that larger $\varepsilon_{\text {ro }}$ can be obtained by enhancing the conjugation length, e.g., incorporating fused rings or increasing the quinoidal contribution. However, there is a limit on the 
delocalization of the charges in organic systems, because the band gap becomes increasingly smaller as the conjugation length increases. Here, we propose a possible strategy to enhance electronic polarization without substantially increasing the conjugation length. Scheme 1 shows a fluorescein monopotassium salt attached to a polymer backbone (note that fluorescein bis-sodium salt has been reported to show semiconducting property $[29,30])$. If the $\mathrm{K}^{+}$cation is located close to the phenolate anion $\left(-\mathrm{PhO}^{-}\right)$in the solid state, the negative electron will be concentrated on the $-\mathrm{PhO}^{-}$. Upon the application of a high enough external electric field, the electron can be polarized to the quinoidal oxygen on the other side of the fluorescein, forming a $-\mathrm{PhO}^{-}$anion, with a substantial increase in the dipole moment. Switching between small (at a zero field) and large (at a high enough field) dipole moments in fluorescein monopotassium phenolate will lead to high electronic polarization and thus a high $\varepsilon_{\text {roo }}$.

In this study, we grafted fluorescein monopotassium salts onto two azide-functionalized poly(styrene-co-chloromethyl styrene) $[\mathrm{P}(\mathrm{S}-\mathrm{co}-\mathrm{CMS})]$ random copolymers with 50 and 75 mol.\% functionality, using the copper-catalyzed azide-alkyne cycloaddition (CuAAC or "click") reaction (Scheme 2). In addition to the bare $\mathrm{K}^{+}$cations, $\mathrm{K}^{+}$complexed with 18 -crown-6 (18C6) was used as the counter cation. The purpose of using the $\mathrm{K}^{+} / 18 \mathrm{C} 6$ complex as the counter cation is to increase the $\mathrm{K}^{+}--\mathrm{PhO}^{-}$distance in order to reduce the strong electrostatic interaction. It is anticipated that the electron on the conjugated rings of fluorescein can be more easily polarized towards the quinoidal oxygen under a high enough electric field, when the $\mathrm{K}^{+}$is at a 
suitable distance away from the $-\mathrm{PhO}^{-}$(see Scheme 1). Therefore, it was intriguing to see whether this strategy could increase the $\varepsilon_{\mathrm{r} \infty}$ for the semiconducting polymers or not.

Scheme 2. (a) Synthesis of fluorescein-containing random copolymers, P1-Flu and P2-Flu, based on P(S-co-CMS) with 50 and 75 mol.\% CMS. (b) Neutralization of P1-Flu and P2-Flu with $\mathrm{K}_{2} \mathrm{CO}_{3}$ yields P1-FluK/P2-FluK and further complexation with 18-crown-6 yields P1-FluKCE/P2-FluKCE.

\section{Experimental}

\subsection{Materials}

Fluorescein (99\%), propargyl alcohol (PA, 99\%), p-(chloromethyl)styrene (CMS, 90\%), and azobisisobutyronitrile (AIBN) was purchased from Sigma-Aldrich. Styrene (99.95\%), N,N-dimethylformamide (DMF, 99.8\%, extra dry), N,N-diisopropylethylamine (DIPEA, 99.95+\%), copper(I) chloride (CuCl, 99.99\%), and 18-crown-6 (18C6, 99\%) was purchased from Acros. Sodium azide $\left(\mathrm{NaN}_{3}\right)$ was purchased from Fisher and used as received. Anhydrous potassium carbonate $\left(\mathrm{K}_{2} \mathrm{CO}_{3}\right)$ was purchased from Fluka. All other solvents were purchased from Fisher and used without further purification. 


\subsection{Synthesis of propargyl fluorescein ester (PA-Flu)}

Fluorescein $(3.32 \mathrm{~g}, 10 \mathrm{mmol})$ and $30 \mathrm{~mL}$ of $\mathrm{PA}$ were placed in a single-necked round-bottom flask immersed in an ice bath. $0.5 \mathrm{~mL}$ of concentrated $\mathrm{H}_{2} \mathrm{SO}_{4}$ the catalyst, was added dropwise over $10 \mathrm{~min}$. The mixture was heated to $90{ }^{\circ} \mathrm{C}$ and reacted overnight. The solution was cooled to room temperature and precipitated into $500 \mathrm{~mL}$ of water. The brown powder was washed three times with $200 \mathrm{~mL}$ water. Thin layer chromatography (TLC) showed that the main impurity was unreacted fluorescein. Column chromatography on fumed silica gel eluted with a methanol/ethyl acetate (1:5) mixture afforded the desired product, PA-Flu (2.3 g, yield 62.2\%). Proton nuclear magnetic resonance $\left({ }^{1} \mathrm{H}\right.$ NMR, $500 \mathrm{MHz}$, DMSO- $\left.\mathrm{d}_{6}\right) \delta: 8.20(\mathrm{~d}$, Ar- $H, 1 \mathrm{H}), 7.88(\mathrm{t}, \mathrm{Ar}-H, 1 \mathrm{H}), 7.79$ (t, Ar- $H, 1 \mathrm{H}), 7.50(\mathrm{~d}, \mathrm{Ar}-H, 1 \mathrm{H}), 6.78(\mathrm{~d}, \mathrm{Ar}-H, 2 \mathrm{H}), 6.56$ (broad, $\mathrm{Ar}-\mathrm{H}, 4 \mathrm{H}), 4.66\left(\mathrm{~s},-\mathrm{COOCH}_{2} \mathrm{C} \equiv \mathrm{CH}, 2 \mathrm{H}\right), 3.41\left(\mathrm{t},-\mathrm{COOCH}_{2} \mathrm{C} \equiv \mathrm{CH}, 1 \mathrm{H}\right)$.

\subsection{Synthesis of $P(S-c o-C M S)$ random copolymers}

P(S-co-CMS) copolymers with 50 (P1) and 75 mol.\% CMS (P2) were prepared by conventional free radical copolymerization from styrene and CMS at $60{ }^{\circ} \mathrm{C}$. An example synthesis procedure for the P1 is described below. Styrene $(5.2 \mathrm{~g}, 50 \mathrm{mmol})$ was passed through basic alumina to remove the inhibitor and then transferred into a Schlenk flask. After adding CMS (7.6 g, $50 \mathrm{mmol}$ ) and AIBN ( $82 \mathrm{mg}, 0.5 \mathrm{mmol})$, the reaction mixture was degassed by the freeze- pump-thaw method three times to remove oxygen. The mixture was then heated to $60^{\circ} \mathrm{C}$ and reacted overnight. The polymerization was terminated by cooling into an ice bath. The yellow glassy solid was dissolved in $50 \mathrm{~mL}$ of toluene and precipitated into $500 \mathrm{~mL}$ of methanol for three times, yielding a white polymer powder. The P2 was synthesized similarly. 
The yields were $76 \%$ for $\mathrm{P} 1$ and $81 \%$ for $\mathrm{P} 2 . \quad{ }^{1} \mathrm{H}$ NMR $\left(500 \mathrm{MHz}, \mathrm{CDCl}_{3}\right) \delta$ : $7.08-6.41$ (broad d, Ar- $H$ ), 4.51 (broad s, $\mathrm{ArCH}_{2} \mathrm{Cl}$ ), 1.75-1.38 (broad d, $-\mathrm{CH}_{2} \mathrm{CH}-$ ). From size-exclusion chromatography (SEC) using PS as standard for calibration, the number-average molecular weights $\left(\mathrm{M}_{\mathrm{n}}\right)$ and polydispersity indices (PDI) were determined. For P1, $\mathrm{M}_{\mathrm{n}}=52,000 \mathrm{~g} / \mathrm{mol}$ and $\mathrm{PDI}=1.9 . \quad$ For $\mathrm{P} 2, \mathrm{M}_{\mathrm{n}}=43,000 \mathrm{~g} / \mathrm{mol}$ and $\mathrm{PDI}=1.9$.

\subsection{Synthesis of azide-functionalized P(S-co-CMS) (P1-N3 and P2-N3)}

An example of the synthesis procedure for the P1-N3 is described below. P1 (5.1 g, 20 mmol of CMS) was dissolved in $30 \mathrm{~mL}$ of dry DMF in a $100 \mathrm{~mL}$ single-necked round-bottom flask, $\mathrm{NaN}_{3}(2.6 \mathrm{~g}, 40 \mathrm{mmol})$ was added and stirred at room temperature under $\mathrm{N}_{2}$ protection overnight. After reaction, the solution was diluted by adding additional $50 \mathrm{~mL}$ of dry DMF, followed by filtration to remove $\mathrm{NaCl}$ and unreacted $\mathrm{NaN}_{3}$. The filtered solution was precipitated into $1 \mathrm{~L}$ of water and washed with methanol to remove residual salts. The procedure was then repeated. Finally, the solid was re-dissolved in $80 \mathrm{~mL}$ of $\mathrm{CHCl}_{3}$ and precipitated into $1 \mathrm{~L}$ of methanol, yielding a white polymer powder $(4.3 \mathrm{~g}$, yield $84.3 \%)$. The P2-N3 was synthesized similarly with a yield of $86.5 \% .{ }^{1} \mathrm{H}$ NMR $\left(500 \mathrm{MHz}, \mathrm{CDCl}_{3}\right) \delta$ : 7.02-6.53 (broad d, Ar-H), 4.22 (broad s, $\mathrm{ArCH}_{2} \mathrm{~N}_{3}$ ), 1.74-1.40 (broad d, - $\mathrm{CH}_{2} \mathrm{CH}$-).

\subsection{The CuAAC click reaction to prepare P1-Flu and P2-Flu}

A degassed solution of PA-Flu (407 mg, $1.1 \mathrm{mmol})$ and DIPEA (174 $\mu \mathrm{L}, 1.0 \mathrm{mmol})$ in dry DMF (10 mL) was added to a degassed solution of either P1-N3 (263 mg, $1.0 \mathrm{mmol}$ azide) or P1-N3 (194 mg, $1.0 \mathrm{mmol}$ azide) and $\mathrm{CuCl}(20 \mathrm{mg}, 0.2 \mathrm{mmol})$ in dry DMF (20 mL) under $\mathrm{N}_{2}$ protection. The mixture was stirred at $50{ }^{\circ} \mathrm{C}$ overnight. The progress of the reaction was 
followed by monitoring the decrease of the azide absorption at $2100 \mathrm{~cm}^{-1}$ using Fourier transform infrared (FTIR) spectroscopy. After reaction, the mixture was cooled to room temperature and passed through an alumina column to remove the copper ions. The polymer solution was precipitated into ethyl acetate to yield an orange solid. From the FTIR result, the efficiency of the click reaction was quantitative. Yields: P1-Flu (1.12 g, 88.4\%) and P2-Flu $(1.02 \mathrm{~g}, 90.6 \%)$.

\subsection{Neutralization of P1-Flu and P2-Flu to yield P1-FluK and P2-FluK}

P1-Flu (633 mg, $1.0 \mathrm{mmol}$ of fluorescein groups) or P2-Flu $(563 \mathrm{mg}, 1.0 \mathrm{mmol}$ of fluorescein groups) was dissolved in $10 \mathrm{~mL}$ of dry DMF and transferred to a single-necked round-bottom flask containing $\mathrm{K}_{2} \mathrm{CO}_{3}(414 \mathrm{mg}, 3.0 \mathrm{mmol})$. The mixture was stirred at $60{ }^{\circ} \mathrm{C}$ overnight and then cooled to room temperature. Unreacted $\mathrm{K}_{2} \mathrm{CO}_{3}$ was removed by filtration and $20 \mathrm{~mL}$ of deionized water was added. The mixed solution was transferred into a dialysis bag (the cutoff molecular weight, $\mathrm{MWCO}=3,500 \mathrm{Da}$ ) and dialyzed in deionized water for two days. The polymer solid in the dialysis bag was filtered, washed with methanol, and dried in a vacuum oven at room temperature, yielding an orange polymer powder. P1-FluK (597 mg,

$88.9 \%$ yield). $\quad{ }^{1} \mathrm{H}$ NMR (500 MHz, DMSO-d $\left.{ }_{6}\right) \delta: 8.05-6.43$ (m, Ar- $\left.H, 19 \mathrm{H}\right), 5.39$ (s, $\left.\mathrm{ArCOOCH}_{2^{-}}, 2 \mathrm{H}\right), 5.02\left(\mathrm{~s}, \mathrm{Ar}-\mathrm{CH}_{2^{-}}, 2 \mathrm{H}\right), 1.62$ (broad s, $\left.-\mathrm{CH}_{2}-\mathrm{CH}-, 6 \mathrm{H}\right) . \quad$ P2-FluK (557 mg, 92.7\% yield). ${ }^{1} \mathrm{H}$ NMR (500 MHz, DMSO-d 6 ) $8: 8.08-6.43$ (broad m, Ar- $H, 47 \mathrm{H}$ ), 5.34 (s, -ArCOOCH $2_{2-}^{-}, 6 \mathrm{H}$ ), 4.98 (s, $\left.\mathrm{Ar}_{-} \mathrm{CH}_{2^{-}}, 6 \mathrm{H}\right), 1.58$ (broad s, - $\mathrm{CH}_{2}-\mathrm{CH}-, 12 \mathrm{H}$ ).

\subsection{Complexation with 18-crown-6 to yield P1-FluKCE and P2-FluKCE}


P1-FluK (335 mg, $0.5 \mathrm{mmol}$ of fluorescein groups) or P2-FluK (301 mg, $0.5 \mathrm{mmol}$ of fluorescein groups) was dissolved in $10 \mathrm{~mL}$ of dry DMF and transferred to a single-necked round-bottom flask containing $18 \mathrm{C} 6(400 \mathrm{mg}, 1.5 \mathrm{mmol})$. The mixture was stirred at $60{ }^{\circ} \mathrm{C}$ overnight and then cooled to room temperature. The solution was precipitated into $100 \mathrm{~mL}$ hexane for three times to remove the excess $18 \mathrm{C} 6$, yielding an orange powder. P1-FluKCE (420 mg, yield 89.9\%). $\quad{ }^{1} \mathrm{H}$ NMR (500 MHz, DMSO-d ${ }_{6}$ ) $8:$ 8.08-6.44 (broad m, Ar- $H, 19 \mathrm{H}$ ), $5.39\left(\mathrm{~s},-\mathrm{ArCOOCH}_{2^{-}}, 2 \mathrm{H}\right), 5.02\left(\mathrm{~s}, \mathrm{Ar}_{-} \mathrm{CH}_{2^{-}}, 2 \mathrm{H}\right), 3.52\left(\mathrm{~s},-\mathrm{OCH}_{2} \mathrm{CH}_{2^{-}}\right.$in $\left.18 \mathrm{C} 6,20 \mathrm{H}\right), 1.62$ (broad, $\left.-\mathrm{CH}_{2}-\mathrm{CH}-, 6 \mathrm{H}\right) . \quad$ P2-FluKCE (402 mg, yield 92.8\%). ${ }^{1} \mathrm{H} \mathrm{NMR}\left(500 \mathrm{MHz}, \mathrm{DMSO}-\mathrm{d}_{6}\right)$ 8: 8.04-6.36 (broad m, Ar- $H, 47 \mathrm{H}), 5.35$ (s, - $\left.\mathrm{ArCOOCH}_{2^{-}}, 6 \mathrm{H}\right), 5.01$ (s, $\left.\mathrm{Ar}_{-} \mathrm{CH}_{2^{-}}, 6 \mathrm{H}\right), 3.76$ (s, $-\mathrm{OCH}_{2} \mathrm{CH}_{2}$ - in $\left.18 \mathrm{C} 6,60 \mathrm{H}\right), 1.52$ (broad, $-\mathrm{CH}_{2}-\mathrm{CH}-, 9 \mathrm{H}$ ).

\subsection{Instruments and characterization methods}

${ }^{1} \mathrm{H}$ NMR spectra were recorded using a Bruker $500 \mathrm{MHz}$ NMR spectrometer. The solvents were $\mathrm{CDCl}_{3}$ for $\mathrm{P} 1 / \mathrm{P} 2$ and $\mathrm{P} 1-\mathrm{N} 3 / \mathrm{P} 2-\mathrm{N} 3$, andDMSO-d 6 for P1-Flu/P2-Flu, P1-FluK/P2-FluK, and P1-FluKCE/P2-FluKCE. The molecular weights of P1 and P2 was determined by SEC using a Water 515 HPLC pump and a Waters 2414 differential refractive index (RI) detector. Tetrahydrofuran (THF) was used as the solvent, and the flow rate was 1.0 $\mathrm{mL} / \mathrm{min}$. PS standards were used for conventional calibration. FTIR spectra were obtained using a Bomem Michelson MB100 FTIR spectrometer, which was equipped with a deuterated triglycine sulfate (DTGS) detector and a dry air (without $\mathrm{CO}_{2}$ ) purge unit. A total of 64 scans were recorded at a resolution of $4 \mathrm{~cm}^{-1}$. The FTIR samples were prepared by drop-casting 50 $\mathrm{mg} / \mathrm{mL}$ of $\mathrm{CHCl}_{3}$-methanol (1:1) mixed polymer solution onto a potassium bromide pellet. Thermogravimetric analysis (TGA) was carried out using a TA instruments Q500 
thermogravimetric analyzer at a heating rate of $10{ }^{\circ} \mathrm{C} / \mathrm{min}$ under a dry nitrogen flow. Differential scanning calorimetry (DSC) was performed on a TA Q100 DSC at a scanning rate of $10^{\circ} \mathrm{C} / \mathrm{min}$.

Two-dimensional (2D) X-ray diffraction (XRD) experiments were performed on a Rigaku MicroMax $002^{+}$diffractometer operated at $45 \mathrm{kV}$ and $0.88 \mathrm{~mA}$. Confocal Max-Flux optics were used to generate a highly focused monochromatic $\mathrm{Cu} \mathrm{K \alpha}$ radiation (wavelength of $0.1542 \mathrm{~nm}$ ) using a sealed tube microfocus X-ray source. Silver behenate was used for calibration of the diffraction angle, and the sample-to-detector distance was ca. $140 \mathrm{~mm} . \quad 2 \mathrm{D}$ XRD patterns were recorded on a Fujifilm imaging plate and scanned using a Fujifilm FLA-7000 scanner at a resolution of $50 \mu \mathrm{m} /$ pixel. One-dimensional (1D) XRD profiles were obtained by integrating the corresponding 2D XRD pattern using the Polar X-ray diffraction software from Stonybrook Technology and Applied Research (Stony Brook, NY).

Broadband dielectric spectroscopy (BDS) measurements were performed on a Novocontrol Concept 80 broadband dielectric spectrometer with temperature control. The applied voltage was $1 \mathrm{~V}_{\text {rms }}(\mathrm{rms}$ means root-mean-square) with the frequency ranging from 0.01 $\mathrm{Hz}$ to $10 \mathrm{MHz}$ and the temperature from -150 to $120{ }^{\circ} \mathrm{C}$. Film samples for BDS characterization were prepared by solution-casting on gold-coated glass slides. P1-FluK and P2-FluK were dissolved in DMAc and P1-FluKCE and P2-FluKCE were dissolved in DMSO. The drop-cast solution on the glass slide was gradually pumped down to vacuum in a vacuum oven during $1 \mathrm{~h}$, and stayed in vacuum for about $4 \mathrm{~h}$. Then, the temperature was raised to 110 ${ }^{\circ} \mathrm{C}$ overnight, and the film was annealed at $140{ }^{\circ} \mathrm{C}$ for $12 \mathrm{~h}$. After drying, typical thickness of the solution-cast films varied from 1.5 to $4 \mu \mathrm{m}$, depending on the concentration of the polymer 
solutions. Gold electrodes $(2.4 \mathrm{~mm}$ in diameter) were deposited on the top surface of the films for the dielectric characterization.

Thin film UV-Vis absorption was performed using a UV-Cary 50 spectrophotometer. Glass substrates were cleaned stepwise in soapy water, deionized water, acetone, and isopropanol under ultrasonication for $15 \mathrm{~min}$. Thin films were obtained from polymer solutions (10 $\mathrm{mg} / \mathrm{mL})$ in DMAc. The solutions were filtered through a $0.45 \mu \mathrm{m}$ PTFE filter and spin-coated at $400 \mathrm{rpm}$ for $60 \mathrm{~s}$ onto the glass substrate. Once dry, the films were annealed at $150{ }^{\circ} \mathrm{C}$ for $15 \mathrm{~min}$.

Thin film cyclic voltammetry $(\mathrm{CV})$ measurements were performed at room temperature using an Auto-Lab-PGSTAT 302N Exo Chemie potentiostat. An electrolyte solution of 0.1 M tetra- $n$-butylammonium hexafluorophosphate in acetonitrile was purged with nitrogen for 10 min prior to conducting the measurements. Glassy carbon (GC) working electrodes were polished sequentially with $1.0,0.3$, and $0.05 \mu \mathrm{m}$ alumina, sonicated in deionized water for $10 \mathrm{~min}$ and dried. Two drops of the polymer solutions in DMAc $(30 \mathrm{mg} / \mathrm{mL})$ were cast on the polished GC electrode until completely dry. A Pt wire was used as the counter electrode while an $\mathrm{Ag} / \mathrm{AgNO}_{3}$ electrode acted as the reference electrode. The half-wave potential $\left(\mathrm{E}_{1 / 2}\right)$ was 0.141 $\mathrm{V}$ as calibrated by ferrocene $(\mathrm{Fc}) / \mathrm{Fc}^{+}$. The scan rate was kept at $0.1 \mathrm{~V} / \mathrm{s}$.

For space-charge limited current (SCLC) measurements, indium tin oxide (ITO)-coated glass substrates ( $\mathrm{R}=15 \Omega /$ sq.) were cleaned stepwise in soapy water, deionized water, acetone, and isopropanol under ultrasonication for $15 \mathrm{~min}$, followed to a $\mathrm{UV}$-ozone treatment at $80{ }^{\circ} \mathrm{C}$ for $15 \mathrm{~min}$. For the electron mobility measurement, an architecture of ITO/Al/polymer/Al was constructed. A layer of $\mathrm{Al}(60 \mathrm{~nm})$ was thermally deposited using a shadow mask under a vacuum pressure of $3 \times 10^{-5}$ torr using an Angstrom Engineering Evovac Deposition System. 
The polymer solutions (in DMAc) were filtered through a $0.45 \mu \mathrm{m}$ PTFE filter and drop cast onto the glass slide inside a glovebox (PureLab HE). The concentration was $50 \mathrm{mg} / \mathrm{mL}$ for P2-FluK and $80 \mathrm{mg} / \mathrm{mL}$ for P2-FluKCE. Once the films dried, the polymer films were annealed at $150{ }^{\circ} \mathrm{C}$ for $15 \mathrm{~min}$, followed by deposition of the top $\mathrm{Al}$ electrode (100 $\left.\mathrm{nm}\right)$ through a shadow mask. For the hole mobility measurement, a poly(3,4-ethylenedioxythiophene):poly(styrene sulfonate) (PEDOT:PSS) layer was prepared onto ITO by spin-coating at 4,000 rpm for $60 \mathrm{~s}$, followed by heating the film at $150{ }^{\circ} \mathrm{C}$ for 10 min in air. The thickness of PEDOT:PSS was about 20-30 nm. The polymer thin film was obtained by spin-coating a $10 \mathrm{mg} / \mathrm{mL}$ solution of P2-FluK or P2-FluKCE in DMAc. The films were annealed at $150{ }^{\circ} \mathrm{C}$ for 15 min once the films were dried. $\quad \mathrm{MoO}_{3}(10 \mathrm{~nm})$ and $\mathrm{Ag}(80 \mathrm{~nm})$ were deposited sequentially through a shadow mask under a vacuum of $3 \times 10^{-5}$ torr using the Angstrom Engineering Evovac Deposition System to construct an ITO/PEDOT:PSS/polymer/ $\mathrm{MoO}_{3} / \mathrm{Ag}$ multilayer structure.[31] Dark current measurements were performed using a Keithley 2400 source meter inside the glovebox. The devices have a total effective area of $0.2 \mathrm{~cm}^{2}$. 


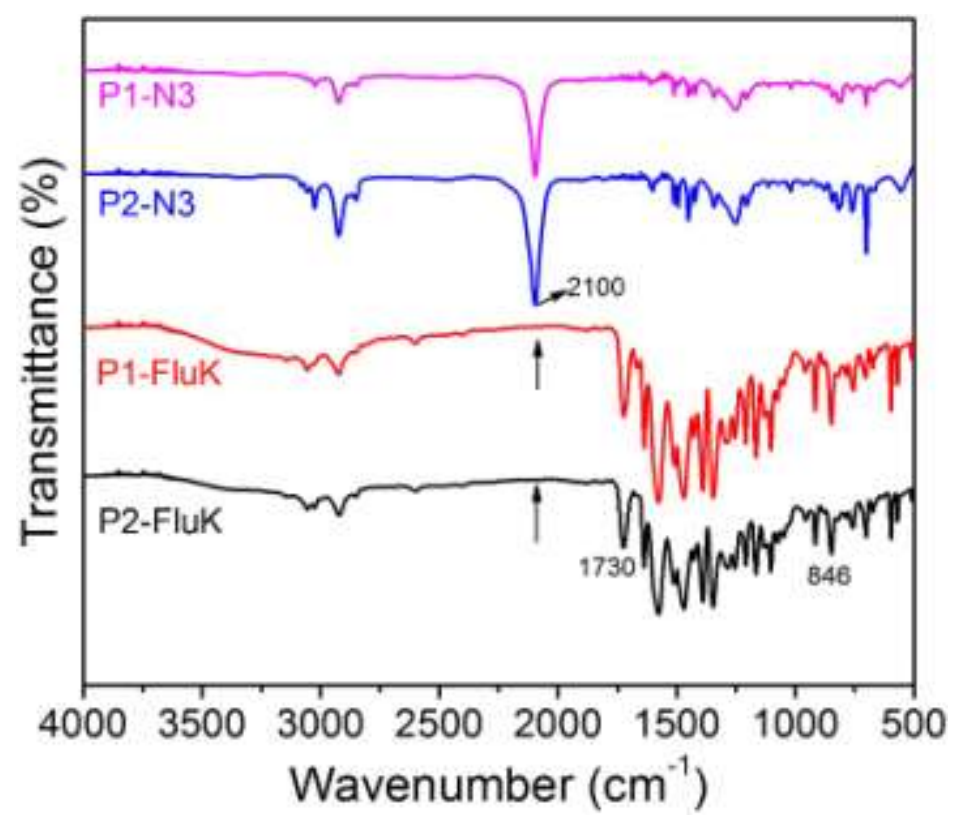

Fig. 1. Transmission FTIR spectra of P1-N3/P2-N3 before the CuAAC click reaction and $\mathrm{P} 1-\mathrm{FluK} / \mathrm{P} 2-\mathrm{FluK}$ after the $\mathrm{CuAAC}$ click reaction.

\section{Results and discussion}

\subsection{Synthesis of fluorescein-containing P1-FluK/P2-FluK and P1-FluKCE/P2-FluKCE}

Using bulk radical polymerization, the precursor $\mathrm{P}(\mathrm{S}-\mathrm{co}-\mathrm{CMS})$ random copolymers were synthesized. The CMS compositions were $50 \mathrm{~mol} \%$ for P1 and $75 \mathrm{~mol} \%$ for P2, as determined by ${ }^{1} \mathrm{H}$ NMR. The $\mathrm{M}_{\mathrm{n}} \mathrm{s}$ were determined by SEC to be around 40-50 $\mathrm{kDa}$ and the PDI values were around 1.9 for both copolymers, suggesting disproportionation as the major termination mechanism. The chloromethyl groups in CMS were easily functionalized by $\mathrm{NaN}_{3}$ in DMF to yield P1-N3 and P2-N3.[32] Subsequently, the azido groups in P1-N3/P2-N3 was coupled with PA-Flu via the CuAAC click reaction in DMF to yield P1-Flu and P2-Flu (Scheme 1a).[33] The success of CuAAC reaction was monitored by FTIR, as shown in Fig. 1. P1-N3 and P2-N3 exhibited a distinct absorption band at $2100 \mathrm{~cm}^{-1}$ from the azido group.[32] After 
the $\mathrm{CuAAC}$ reaction and treatment with $\mathrm{K}_{2} \mathrm{CO}_{3}$, P1-FluK and P2-FluK had no absorption at 2100 $\mathrm{cm}^{-1}$, suggesting the complete conversion of the azido groups in P1-N3 and P2-N3 after the CuAAC "click" reaction. Most absorption bands between 1730 and $846 \mathrm{~cm}^{-1}$ were ascribed to the fluorescein moieties in P1-FluoK and P2-FluoK.[34]

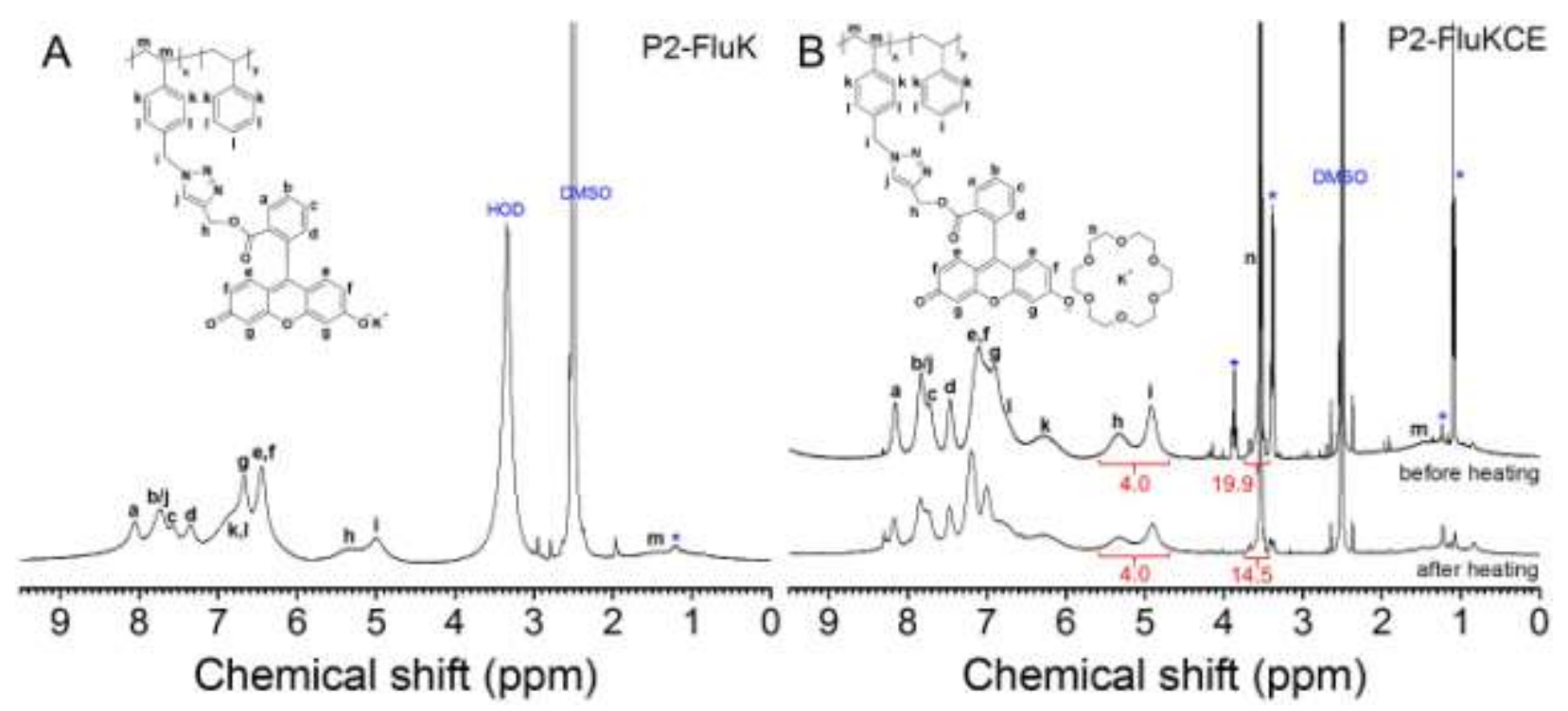

Fig. 2. ${ }^{1} \mathrm{H}$ NMR spectra of (A) P2-FluK and (B) P2-FluKCE, respectively. DMSO-d $\mathrm{d}_{6}$ is used as the solvent. For the P2-FluKCE before and after heating/drying at $120{ }^{\circ} \mathrm{C}$ in vacuum for 12 $\mathrm{h}$, a drop of trifluoroacetic acid was added to shift the water peak beyond $10 \mathrm{ppm}$. Impurity solvent peaks are labeled with stars.

To obtain P1-FluKCE and P2-FluKCE, P1-FluK and P2-FluK reacted with 18C6, followed by dialysis to remove excess 18C6. The corresponding ${ }^{1} \mathrm{H}$ NMR spectra for P2-FluK and P2-FluKCE are shown in Figs. 2A/B, respectively. For the P2-FluK, all protons could be assigned (Fig. 2A). Since proton a appeared at $8.20 \mathrm{ppm}$ for the PA-Flu (see section 2.2 in Experimental), the proton $\mathrm{j}$ on the triazole ring must overlap with proton $\mathrm{b}$ in the fluorescein ring at $7.74 \mathrm{ppm}$. It was interesting to see that protons e-g were identical in phenolate and quinone 
rings in fluorescein. This could be attributed to the fact that the $\mathrm{K}^{+}$cations were not tightly bound to the $-\mathrm{PhO}^{-}$anions in the polar DMSO. They were solvated and randomly distributed in the solution. As a result, the negative charge was more or less uniformly distributed in the conjugated three rings in fluorescein, and protons e-g became identical, regardless they were in the phenolate or quinone rings. After complexation with 18C6 (P2-FluKCE), the sharp peak at $3.54 \mathrm{ppm}$ was assigned to proton $\mathrm{n}$ in $18 \mathrm{C} 6$ (Fig. $2 \mathrm{~B}$ ). The positions for protons $\mathrm{e} / \mathrm{f}$ and $\mathrm{g}$ in P2-FluKCE swapped when compared to those in P2-FluK (Fig. 2A). This was attributed to the environment change after $18 \mathrm{C} 6$ complexation with $\mathrm{K}^{+}$. Again, the $\mathrm{K}^{+} / 18 \mathrm{C} 6$ cations were randomly distributed in the DMSO solvent, and the e-g protons in the phenolate and quinone rings in fluorescein became identical. From peak integration, the proton molar ratio of h/i $(4 \mathrm{H})$ to $18 \mathrm{C} 6(19.9 \mathrm{H})$ was about $1: 5$, which was less than the expected ratio of $1: 6$ for the $1: 1$ complexation of $18 \mathrm{C} 6$ with $\mathrm{K}^{+}$. This could be attributed to the steric hindrance to complex every $\mathrm{K}^{+}$in the 75 mol.\% P2-FluKCE copolymer. In addition, the thermal stability of the $\mathrm{K}^{+} / 18 \mathrm{C} 6$ complexes was studied by heating (or drying) the sample in a vacuum oven at $120^{\circ} \mathrm{C}$ for $12 \mathrm{~h}$. After heating, the proton molar ratio of $\mathrm{h} / \mathrm{i}(4 \mathrm{H})$ to $18 \mathrm{C} 6(14.5 \mathrm{H})$ decreased to 1:3.6. This result indicated that after high temperature vacuum treatment, about $60 \%$ of the $\mathrm{K}^{+}$cations in P2-FluKCE were still complexed with 18C6.
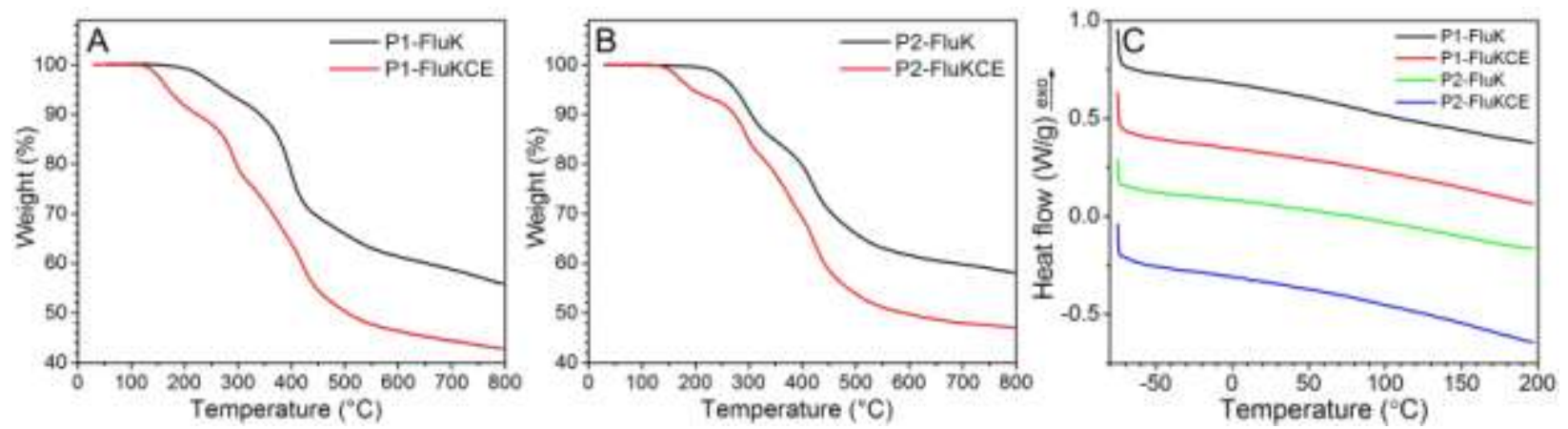
Fig. 3. TGA curves for (A) P1-FluK and P1-FluKCE and (B) P2-FluK and P2-FluKCE. The heating rate was $10{ }^{\circ} \mathrm{C} / \mathrm{min}$ under a dry nitrogen flow. (C) Second heating DSC curves for P1-FluK, P1-FluKCE, P2-FluK, and P2-FluKCE. The heating rate is $10^{\circ} \mathrm{C} / \mathrm{min}$.

\subsection{Thermal properties}

Thermal properties of the fluorescein-containing copolymers were further investigated by TGA (Fig. 3). For P1-FluK/P2-FluK, two major thermal degradation processes were observed. The first step weight loss started at $176{ }^{\circ} \mathrm{C}$, which could be attributed to the thermal degradation of the fluorescein moieties. The second step started at $325{ }^{\circ} \mathrm{C}$, which could be ascribed to the degradation of the PS main chain. Above $550{ }^{\circ} \mathrm{C}$, a char yield of 55 wt. $\%$ was observed for both samples due to the aromatic structure of fluorescein. For P1-FluKCE and P2-FluKCE, an additional weight loss step started at $130{ }^{\circ} \mathrm{C}$, which could be attributed to the thermal evaporation of $18 \mathrm{C} 6$ (boiling point $116^{\circ} \mathrm{C}$ ) even though they were complexed with $\mathrm{K}^{+}$. From the weight losses around $200{ }^{\circ} \mathrm{C}$, i.e., 9 wt.\% for P1-FluKCE and 7 wt.\% for P2-FluKCE, it was calculated that $29 \%$ and 25\% 18C6 were lost upon heating for P1-FluKCE and P2-FluKCE, respectively. Note that these values were less than that $(40 \%)$ after heating at $120{ }^{\circ} \mathrm{C}$ for $12 \mathrm{~h}$ in vacuum (see Fig. 2B). Clearly, vacuum further helped the thermal evaporation of $18 \mathrm{C} 6$ in the samples.

In the following studies, high temperature $\left(120-150{ }^{\circ} \mathrm{C}\right)$ treatment was used to remove high boiling point polar solvents such as DMAc and DMSO after solution-casting or spin-coating for the film preparation. As such, the P1-FluKCE and P2-FluKCE films should contain about 70 mol.\% 18C6. In addition, the P1-FluK/P2-FluK and P1-FluKCE/P2-FluKCE 
samples did not show any obvious phase transitions from $-80{ }^{\circ} \mathrm{C}$ to $200{ }^{\circ} \mathrm{C}$ in DSC (Fig. 3C). This could be attributed to the rigid chemical structures and potential crystallinity in these polymers. Given the solid appearance and hardness of these films, the glass transition temperature $\left(\mathrm{T}_{\mathrm{g}}\right)$ must be higher than $200^{\circ} \mathrm{C}$ (i.e., the degradation of fluorescein).

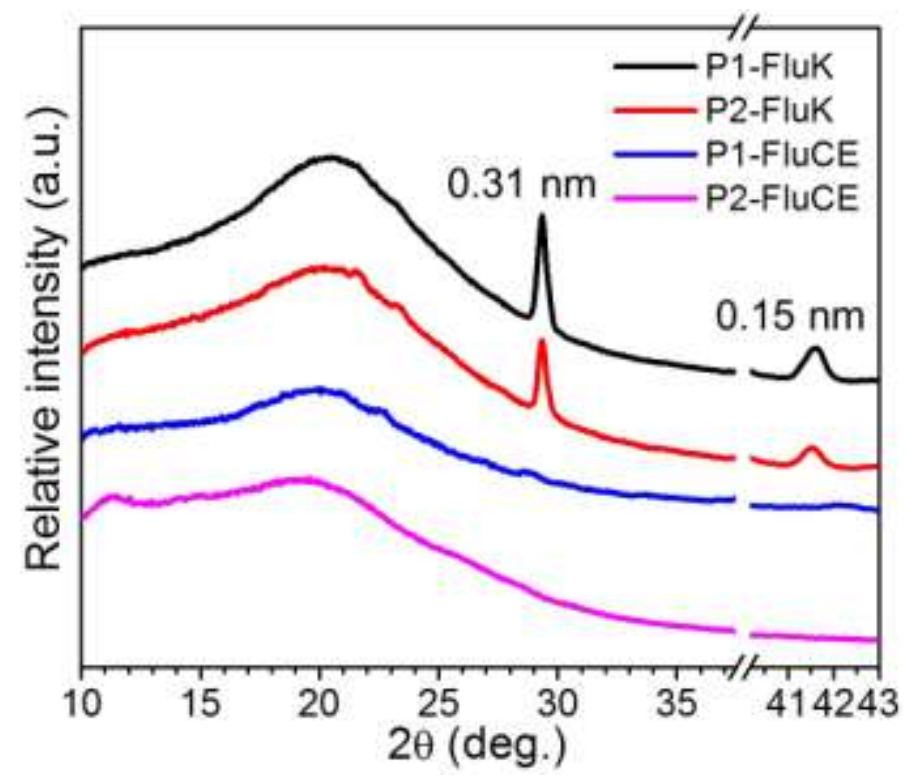

Fig. 4. Powder XRD profiles for P1-FluK, P2-FluK, P1-FluKCE, and P2-FluKCE, respectively, at room temperature, respectively. 


\subsection{Powder XRD of fluorescein-containing polymers}

Fig. 4 shows the powder XRD profiles for P1-FluK/P2-FluK and P1-FluKCE/P2-FluKCE). For P1-FluK and P2-FluK, sharp crystalline reflections were observed at $2 \theta=29.34^{\circ}(0.31 \mathrm{~nm})$ and $41.60^{\circ}(0.15 \mathrm{~nm})$, and the crystallinities were estimated to be 5 and 3 wt.\%, respectively. Judging from the corresponding $d$-spacing of $0.31 \mathrm{~nm}$, the peak at $29.34^{\circ}$ could be possibly attributed to the $\pi$ - $\pi$ stacking of the fluorescein rings in the copolymers. Compared with common $\pi-\pi$ stacking systems $(0.34-0.36 \mathrm{~nm}),[35,36]$ this $d$-spacing is fairly small. In the literature, small $\pi$ - $\pi$ stacking distances were reported and relatively high charge carrier mobilities were obtained as a result of the tight $\pi-\pi$ stacking in the crystalline or liquid crystalline structures.[37, 38] For P1-FluKCE and P2-FluKCE, only amorphous halos were observed, indicating that complexation with $18 \mathrm{C} 6$ made the fluorescein polymers disordered. Films of both P2-FluK and P2-FluKCE tended to be very brittle, pointing to the strong tendency of fluorescein dyes to aggregate in films. 

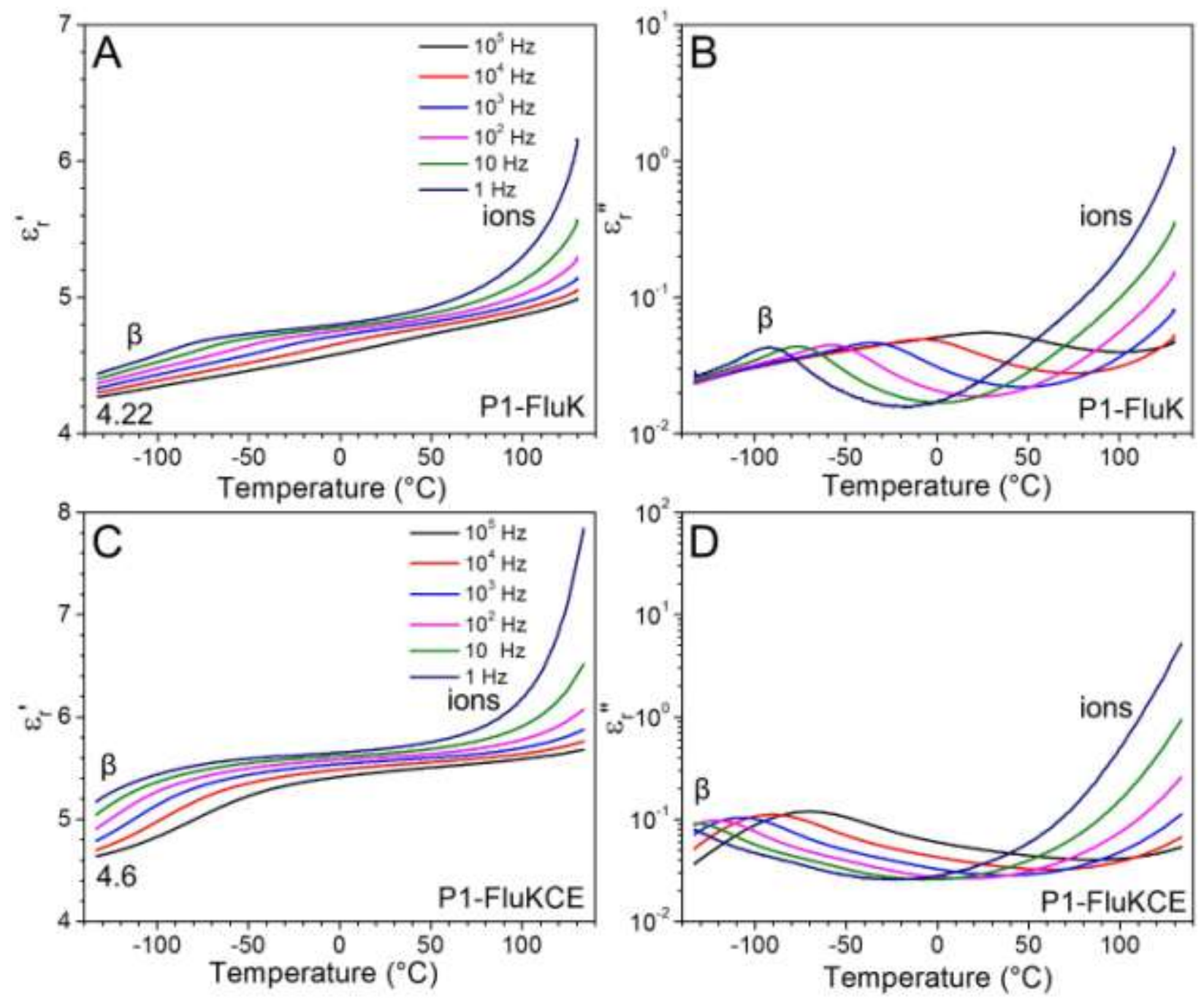

Fig. 5. (A, C) Real $\left(\varepsilon_{\mathrm{r}}{ }^{\prime}\right)$ and $(\mathrm{B}, \mathrm{D})$ imaginary $\left(\varepsilon_{\mathrm{r}}{ }^{\prime \prime}\right)$ parts of relative permittivity as a function of temperature for (A, B) P1-FluK and (C, D) P1-FluKCE at various frequencies.

\subsection{Permittivity study by $B D S$}

The dielectric properties for the fluorescein-containing copolymers with (P1-FluKCE/P2-FluKCE) and without 18C6 (P1-FluK/P2-FluK) were studied by BDS. Fig. 5 shows the real part $\left(\varepsilon_{\mathrm{r}}{ }^{\prime}\right)$ and the imaginary part $\left(\varepsilon_{\mathrm{r}}{ }^{\prime \prime}\right)$ of the relative permittivity as a function of temperature for P1-FluK and P1-FluKCE, respectively, at different frequencies $\left(1-10^{5} \mathrm{~Hz}\right) . \quad$ As 
we mentioned above, the $\mathrm{T}_{\mathrm{g}} \mathrm{s}$ of P1-FluK and P1-FluKCE were above $200{ }^{\circ} \mathrm{C}$; therefore, no $\mathrm{T}_{\mathrm{g}}$ was observed for both copolymers below $150{ }^{\circ} \mathrm{C}$. Instead, increased $\varepsilon_{\mathrm{r}}{ }^{\prime}$ and $\varepsilon_{\mathrm{r}}{ }^{\prime \prime}$ were observed at high temperatures $\left(>100{ }^{\circ} \mathrm{C}\right)$ and low frequencies $(<1 \mathrm{kHz})$. This could be attributed to impurity ion conduction in the glassy sample. Note that similar ionic conduction was also reported for a dipolar glass polymer below its $\mathrm{T}_{\mathrm{g}} \cdot[39]$ At low temperatures, a sub- $\mathrm{T}_{\mathrm{g}}$ transition (i.e., the $\beta$ transition) was observed for both samples, namely, $-92{ }^{\circ} \mathrm{C}$ for P1-FluK and $<-140{ }^{\circ} \mathrm{C}$ for P1-FluKCE at $1 \mathrm{~Hz}$. This $\beta$ transition could be attributed to dipolar polarization of the triazole rings, which had a dipole moment of 4.38 D.[40] Compared with P1-FluK, the $\beta$ transition for the P1-FluKCE appeared at lower temperatures. This could be attributed to the presence of the soft 18C6, which increased the dipole mobility in P1-FluKCE. 

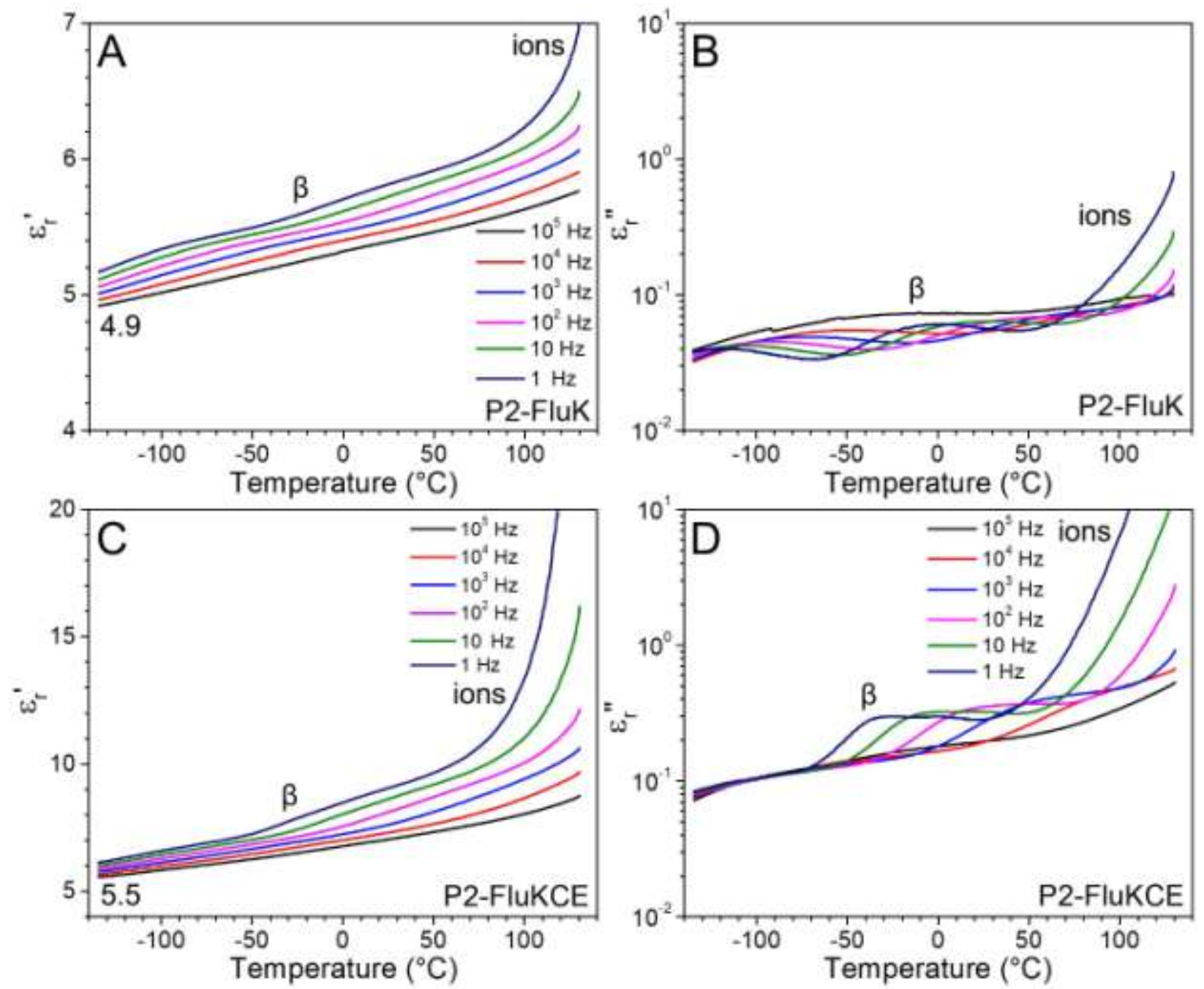

Fig. 6. (A, C) Real $\left(\varepsilon_{\mathrm{r}}{ }^{\prime}\right)$ and $(\mathrm{B}, \mathrm{D})$ imaginary $\left(\varepsilon_{\mathrm{r}}{ }^{\prime \prime}\right)$ parts of relative permittivity as a function of temperature for $(\mathrm{A}, \mathrm{B}) \mathrm{P} 2-\mathrm{FluK}$ and $(\mathrm{C}, \mathrm{D}) \mathrm{P} 2-\mathrm{FluKCE}$ at various frequencies.

Fig. 6 shows $\varepsilon_{\mathrm{r}}{ }^{\prime}$ and $\varepsilon_{\mathrm{r}}{ }^{\prime \prime}$ as a function of temperature for P2-FluK and P2-FluKCE, respectively. Again, the increases in $\varepsilon_{\mathrm{r}}{ }^{\prime}$ and $\varepsilon_{\mathrm{r}}{ }^{\prime \prime}$ at high temperatures $\left(>100{ }^{\circ} \mathrm{C}\right)$ and low frequencies $(<1 \mathrm{kHz})$ were attributed to the impurity ion conduction in the samples even below their $\mathrm{T}_{\mathrm{g}}$. Compared with $\mathrm{P} 1-\mathrm{FluK}$, the $\beta$ transition at $1 \mathrm{~Hz}$ increased to $-15^{\circ} \mathrm{C}$ for P2-FluK. This could be attributed to the increase in fluorescein content from 50 to $75 \mathrm{~mol} \%$, which enhanced the rigidity of the sample. After complexation with $18 \mathrm{C} 6$ in P2-FluKCE, the $\beta$ 
transition at $1 \mathrm{~Hz}$ decreased to $-35{ }^{\circ} \mathrm{C}$ due to the enhanced mobility of the triazole dipoles with the help of 18C6. For the P2-FluK, there was an additional weak sub- $\mathrm{T}_{\mathrm{g}}$ transition around -135 ${ }^{\circ} \mathrm{C}$ at $1 \mathrm{~Hz}$ (Fig. 6B); however, it disappeared for the P2-FluKCE (Fig. 6D). We speculate that this low temperature sub- $\mathrm{T}_{\mathrm{g}}$ transition might be related to the moisture absorbed in the sample, despite stringent drying for the sample. Note that absorbed moisture can often induce low temperature transition for polar polymers such as Kapton.[41]

With these sub- $\mathrm{T}_{\mathrm{g}}$ dipolar transitions, the static dielectric constant $\left(\varepsilon_{\mathrm{rs}}\right)$ at low frequencies was enhanced. In other words, these polymers can be considered as dipolar glasses.[39] For example, the $\varepsilon_{\mathrm{rs}}$ values were 4.92 and 5.7 for P1-FluK and P2-FluK, and 5.8 and 9.0 for P1-FluKCE and P2-FluKCE, respectively, at room temperature and $1 \mathrm{~Hz}$. However, the goal of this study was to achieve enhanced electronic polarization $\left(\varepsilon_{\mathrm{r} \infty}\right)$ for the rationally designed semiconducting polymers in Scheme 1. Because electronic polarization does not depend much on temperature,[10] the low temperature and high frequency $\varepsilon_{\mathrm{r}}{ }^{\prime}$ values can be used to estimate the $\varepsilon_{\mathrm{r} \infty}$ in these copolymers. At $-140{ }^{\circ} \mathrm{C}$ and $10^{5} \mathrm{~Hz}$, the $\varepsilon_{\mathrm{r} \infty}$ was 4.22 and 4.9 for P1-FluK and P2-FluK, and 4.6 and 5.5 for P1-FluKCE and P2-FluKCE, respectively. For comparison, the $\varepsilon_{\mathrm{r} \infty}$ for the $\mathrm{P}(\mathrm{S}-\mathrm{co}-\mathrm{CMS})$ without fluorescein is about 2.5. The increase in $\varepsilon_{\mathrm{r} \infty}$ with increasing fluorescein content is consistent with fluorescein being responsible for the high $\varepsilon_{\mathrm{r} \infty}$. Comparing the $\varepsilon_{\mathrm{r} \infty}$ values of P1-FluKCE/P2-FluKCE with those of P1-FluK and P2-FluK, there were indeed some increases in $\varepsilon_{\mathrm{r} \infty}$ with complexation with $18 \mathrm{C} 6$; however, the increases were not as high as we had expected. 
This observation could have two very different possible explanations. First, similar to the solution NMR results in Fig. 1, both $\mathrm{K}^{+}$and $\mathrm{K}^{+} / 18 \mathrm{C} 6$ cations may not be in the close vicinity of the $-\mathrm{PhO}^{-}$anions even in the solid state. As a result, the electron could be evenly distributed in the conjugated ring structure of fluorescein, and the $\varepsilon_{\text {ro }}$ with and without $18 \mathrm{C} 6$ become similar. However, the solid-state situation should be very different from the solution environment, because there are no solvated cations and anions in the bulk and the strong electrostatic attraction will bring $\mathrm{K}^{+}$and $-\mathrm{PhO}^{-}$together. For example, in the potassium phenoxide crystal, the distance between $\mathrm{K}^{+}$and $-\mathrm{PhO}^{-}$is $0.26 \mathrm{~nm},[42]$ whereas the $\mathrm{K}^{+}$- $-\mathrm{PhO}^{-}$ distance only slightly increases to $0.31 \mathrm{~nm}$ in the 1:1:1 complex crystal of dicyclohexano-18-crown-6, potassium phenoxide, and phenol.[43] This is primarily attributed to the relatively flat structure of $\mathrm{K}^{+} / 18 \mathrm{C} 6$ in the complex crystal, and thus the increase of the $\mathrm{K}^{+}$$-\mathrm{PhO}^{-}$distance is not as large as expected. This could explain the experimental observation that the increase in $\varepsilon_{\mathrm{r} \infty}$ after complexing $\mathrm{K}^{+}$with $18 \mathrm{C} 6$ was not as large as expected. In the future, a larger organic cation needs to be used to enhance the proposed field-dependent tautomerism in Scheme 1. Research is currently underway to achieve high $\varepsilon_{\mathrm{r} \infty}$ fluorescein-containing semiconducting polymers. 

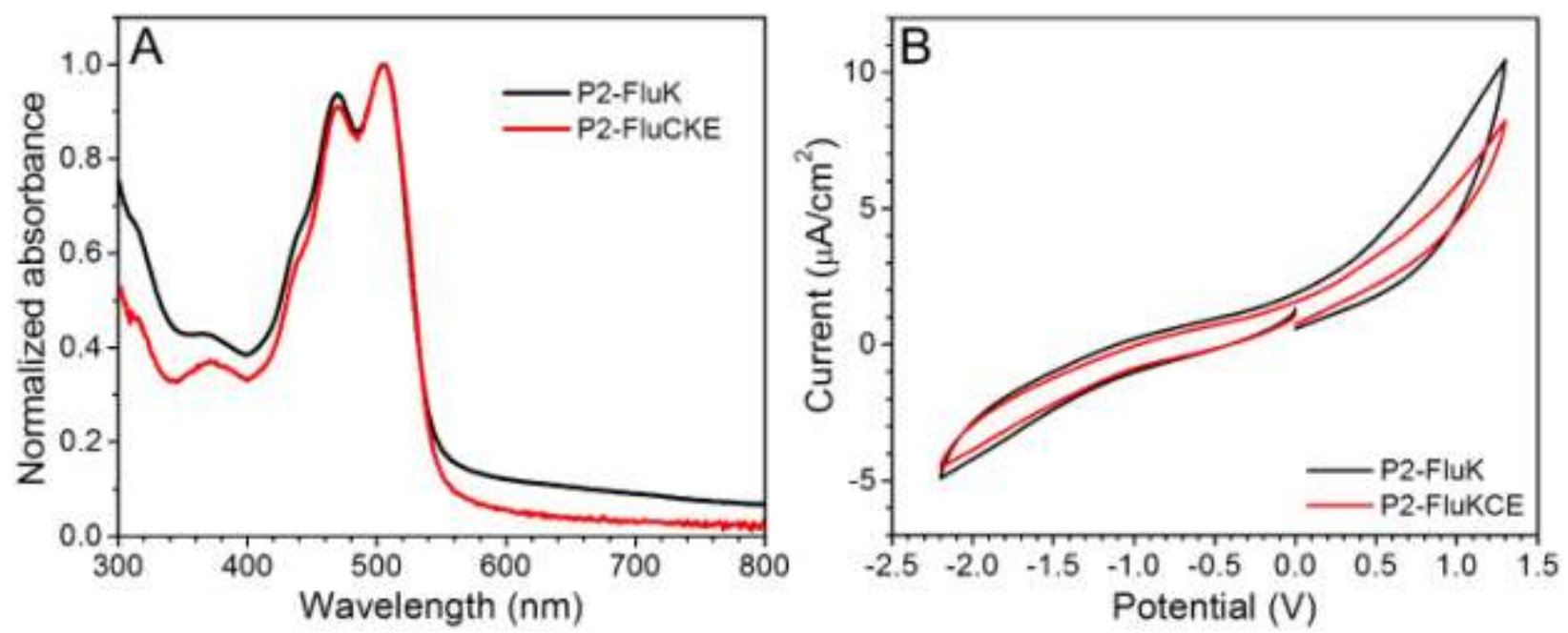

Fig. 7. (A) Thin-film UV-Vis spectra for P2-FluK and P2-FluKCE. (B) Thin film cyclic voltammetry (CV) curves for P2-FluK and P2-FluKCE.

\subsection{Semiconducting properties of P2-FluK and P2-FluKCE}

Thin film UV-Vis measurements were performed to calculate the optical band gap $\left(\mathrm{E}_{\mathrm{g}}\right)$ for P2-FluK and P2-FluKCE. From the UV-Vis spectra in Fig. 7A, the onset wavelength ( $\left.\lambda_{\text {onset }}\right)$ of P2-FluK and P2-FluKCE were 547.6 and $549.2 \mathrm{~nm}$, respectively (Table 1). Margulies et al. reported that the $\lambda_{\text {onset }}$ for mono-anion fluorescein salt was about $520 \mathrm{~nm}$.[44] Therefore, the onset wavelength of P2-FluK and P2-FluKCE were red-shifted. The optical band gap was determined using the relation: $\mathrm{E}_{g}=h c / \lambda_{\text {onset }}$, where $h$ is the Planck constant and $c$ is the speed of light. The $\mathrm{E}_{\mathrm{g}}$ was $2.26 \mathrm{eV}$ for both P2-FluK and P2-FluKCE.

Thin film $\mathrm{CV}$ curves are shown in Fig. 7B. For both P2-FluK and P2-FluKCE, no obvious oxidation or reduction peaks could be identified within the potential range studied. Therefore, the highest occupied and lowest unoccupied molecular orbital (HOMO and LUMO) levels could not be obtained using this thin film CV measurement. Supposedly, fluorescein 
monosalt could be reduced into the phenol monosalt, whereas the oxidized bisquinone was not stable. We speculate that the hydrophobic PS main chains might segregate to the top surface during drop-casting on the polished electrode because of their low surface energy. Consequently, they might have blocked the electrochemical reaction of fluorescein monosalt polymers. In the future, HOMO energy levels should be measured by photoelectron microscopy or estimated using density functional theory (DFT) calculations.

Table 1. Semiconducting Properties of P2-FluK and P2-FluKCE

\begin{tabular}{ccccccc}
\hline Sample & $\begin{array}{c}\lambda_{\text {onset }} \\
(\mathrm{nm})\end{array}$ & $\begin{array}{c}\text { Optical band } \\
\text { gap (E }, \mathrm{E}, \mathrm{eV})\end{array}$ & $\varepsilon_{\mathrm{r} \infty}$ & $\begin{array}{c}\varepsilon_{\mathrm{rs}}(\mathrm{RT} / \\
1 \mathrm{~Hz})\end{array}$ & $\mu_{\mathrm{e}}\left[\mathrm{cm}^{2} /(\mathrm{V} \cdot \mathrm{s})\right]^{\mathrm{a}}$ & $\mu_{\mathrm{h}}\left[\mathrm{cm}^{2} /(\mathrm{V} \cdot \mathrm{s})\right]^{\mathrm{b}}$ \\
\hline P2-FluK & 547.6 & 2.26 & 4.9 & 5.6 & 0.181 & $1.71 \times 10^{-5}$ \\
P2-FluKCE & 549.2 & 2.26 & 5.5 & 9.0 & 0.153 & - \\
\hline
\end{tabular}

${ }^{a}$ Electron mobility is measured for drop-cast thick films (ca. $\left.1 \mu \mathrm{m}\right)$.

${ }^{\mathrm{b}}$ Hole mobility is measured for spin-coated thin films (ca. $55 \mathrm{~nm}$ ).
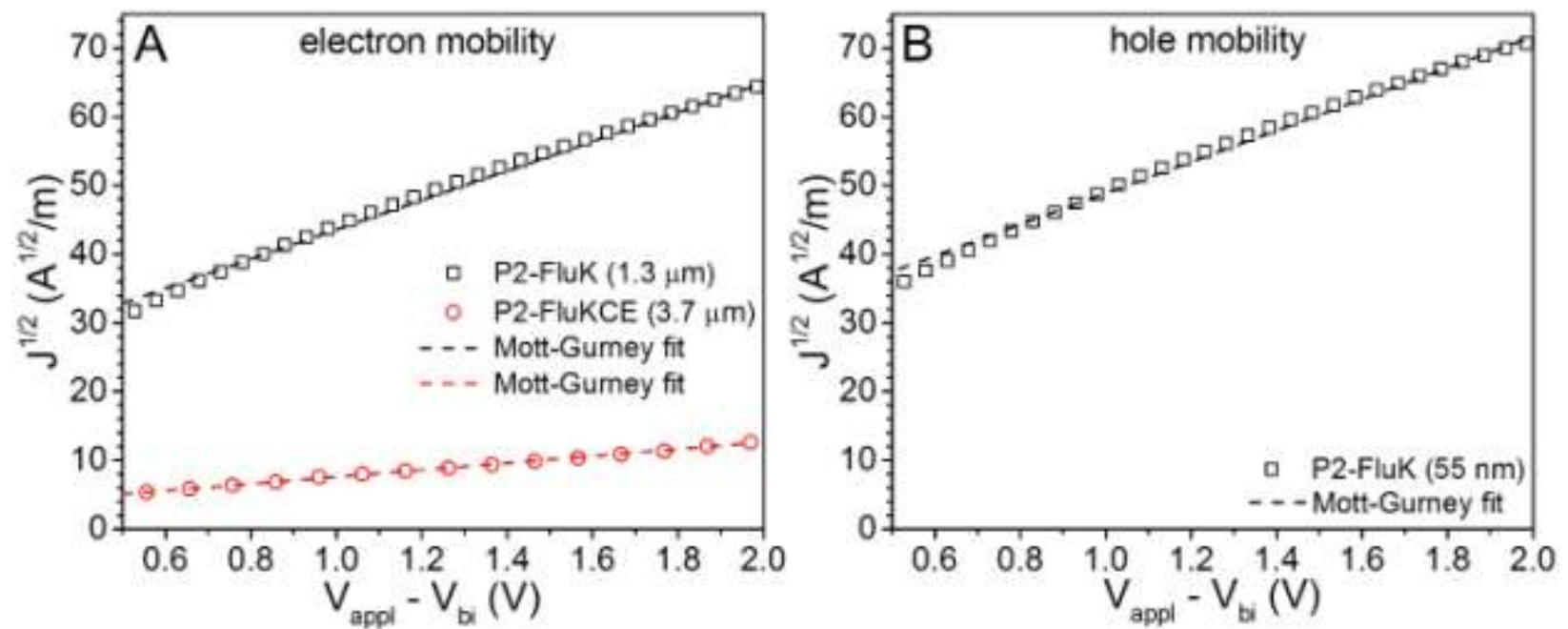

Fig. 8. Room temperature SCLC mobility measurements for P2-FluK and P2-FluKCE: (A) electron mobility and (B) hole mobility. 
Charge carrier mobility can be determined by fitting the dark current to the model of a single carrier with the SCLC model, which is described by the Mott-Gurney square law: [10]

$$
J=\frac{9}{8} \varepsilon_{0} \varepsilon_{r} \mu \frac{V^{2}}{d^{3}}
$$

$\varepsilon_{0}$ and $\varepsilon_{\mathrm{r}}$ are the permittivity of vacuum and the dielectric materials, respectively. $\mu$ is the electron or hole mobility, $V$ is the applied voltage, and $d$ is the layer thickness. The applied voltage was corrected for the built-in voltage ( $\mathrm{V}_{\mathrm{bi}}, 0$ for electron-only devices). The charge carrier mobility can be calculated from the slope of the $\mathrm{J}^{1 / 2}-\mathrm{V}$ curves.

$\mathrm{J}-\mathrm{V}$ measurements were performed for an ITO/Al/polymer/Al electron-only diode at room temperature in the dark (Fig. 8A) to estimate the electron mobility of P2-FluK and P2-FluKCE. The current density depended quadratically on the applied voltage at room temperature, indicative of the SCLC charge transport. The calculated room temperature electron mobilities of P2-FluK and P2-FluKCE were 0.181 and $0.153 \mathrm{~cm}^{2} /(\mathrm{V} \cdot \mathrm{s})$, respectively, for $1 \mu \mathrm{m}$ drop-cast films (Table 1 ), and $3 \times 10^{-5} \mathrm{~cm}^{2} /(\mathrm{V} \cdot \mathrm{s})$ for $33-43 \mathrm{~nm}$ spin-coated films. These results suggest that the slower film formation conditions for drop-casting may allow morphological features that significantly enhance electron mobility in these materials. Hole mobility could only be obtained for thin spin-coated films of polymer using the device configuration of ITO/PEDOT:PSS/polymer/ $\mathrm{MoO}_{3} / \mathrm{Ag}$ in the dark, as drop-cast films easily peeled off from the substrate. The estimated hole mobility for P2-FluK was $1.71 \times 10^{-5}$ $\mathrm{cm}^{2} /(\mathrm{V} \cdot \mathrm{s})$. 
From these measurements, the fluorescein-containing polymers behaved as $n$-type semiconductors, which is different from the report for the fluorescein sodium salt.[29] The electron mobility measured by SCLC is somewhat higher than other $n$-type semiconducting polymers.[45] Given the low crystallinity of P2-FluK and the amorphous P2-FluKCE, we consider that the relatively high $\varepsilon_{\mathrm{rod}} / \varepsilon_{\mathrm{rs}}$ of these samples should be responsible for the observed high electron mobility. Despite the higher $\varepsilon_{\mathrm{ro}} / \varepsilon_{\mathrm{rs}}$ values, the electron mobility for P2-FluKCE was slightly lower than that for P2-FluK, suggesting that the crystallinity in P2-FluK might have helped electron transport. For the hole mobility of P2-FluKCE, we couldn't obtain legitimate results, because the amorphous film was ultra-brittle and broke into small pieces after solution-casting on top of the PEDOT-PSS thin film $(20-30 \mathrm{~nm})$. In the future, more experiments need to be carried out to fully understand the high electron mobility in these fluorescein-containing copolymers.

\section{Conclusions}

In summary, a new strategy has been designed to enhance the electronic polarization and thus the $\varepsilon_{\mathrm{r} \infty}$ for semiconducting fluorescein monopotassium salt copolymers, utilizing the electric field-induced tautomerism in Scheme 1. The fluorescein-containing polymers were successfully synthesized using the CuAAC click reaction to graft PA-Flu onto the azide-functionalized $\mathrm{P}(\mathrm{S}-\mathrm{co}$-CMS) random copolymers with 50 and $75 \mathrm{~mol} . \%$ functionality. After neutralization, fluorescein monopotassium salt polymers were obtained. To reduce the 
strong electrostatic attraction between the $\mathrm{K}^{+}$cation and the $-\mathrm{PhO}^{-}$anion, $18 \mathrm{C} 6$ was used to complex with $\mathrm{K}^{+}$to enlarge the distance between $\mathrm{K}^{+}$and $-\mathrm{PhO}^{-}$. Indeed, enhanced $\varepsilon_{\mathrm{r} \infty}$ up to 5.5 (P2-FluKCE) was obtained after complexation with 18C6. Nonetheless, the increase of $\varepsilon_{\text {ro }}$ was not as large as expected. This could be attributed to the slightly increased distance between the $\mathrm{K}^{+} / 18 \mathrm{C} 6$ cations and the $-\mathrm{PhO}^{-}$anions in the solid state due to the relatively flat conformation of $\mathrm{K}^{+} / 18 \mathrm{C} 6$. In addition, XRD result showed very small $\pi$ - $\pi$ stacking distance $(0.310 \mathrm{~nm})$ between neighboring aromatic rings in fluorescein crystals. Both the small $\pi-\pi$ stacking distance in the crystalline structure and relatively high $\varepsilon_{\mathrm{rs}}(5.8-9.0)$ led to the high electron mobilities of 0.181 and $0.153 \mathrm{~cm}^{2} /(\mathrm{V} \cdot \mathrm{s})$ for P2-FluK and P2-FluKCE, respectively. From the UV-Vis study, the optical band gap was $2.26 \mathrm{eV}$. A new strategy is being developed to further enlarge the distance between the $\mathrm{K}^{+}$cation and the $-\mathrm{PhO}^{-}$anion in fluorescein-containing semiconducting polymers in order to further increase the $\varepsilon_{\mathrm{r} \infty}$.

\section{Acknowledgments}

This work is partly supported by National Science Foundation (NSF) Division of Materials Research (DMR) Polymers Program (DMR-0423914). SP and GS acknowledges partial support from NSF (CHEM-1148652). Z. Zhao and HL thank the support from National Science Foundation of China (21274135 and 21174137) and Doctoral Fund of Ministry of Education of China (20133402110042). 


\section{References}

[1] T.A. Skotheim, J.R. Reynolds, Handbook of Conducting Polymers, 3rd ed., CRC Press, Boca Raton, FL, 2007.

[2] F. So, Organic Electronics: Materials, Processing, Devices and Applications, CRC Press, Boca Raton, FL, 2010.

[3] W.C. Dunlap, R.L. Watters, Direct measurement of the dielectric constants of silicon and germanium, Phys. Rev. 92 (1953) 1396-1397.

[4] M.A. Green, A. Ho-Baillie, H.J. Snaith, The emergence of perovskite solar cells, Nature Photon. 8 (2014) 506-514.

[5] S.Y. Leblebici, T.L. Chen, P. Oalde-Veasco, W. Yang, B. Ma, Reducing exciton binding energy by increasing thin film permittivity: An effective approach to enhance exciton separation efficiency in organic solar cells, ACS Appl. Mater. Interfaces 5 (2013) 10105-10110.

[6] L. Zhu, Exploring strategies for high dielectric constant and low loss polymer dielectrics, J. Phys. Chem. Lett. 5 (2014) 3677-3687.

[7] E. Allahyarov, H. Lowen, L. Zhu, Dipole correlation effects on the local field and the effective dielectric constant in composite dielectrics containing high-k inclusions, Phys. Chem. Chem. Phys. 18 (2016) 19103-19117.

[8] L.J.A. Koster, S.E. Shaheen, J.C. Hummelen, Pathways to a new efficiency regime for organic solar cells, Adv. Energy Mater. 2 (2012) 1246-1253. 
[9] N. Camaioni, R. Po, Pushing the envelope of the intrinsic limitation of organic solar cells, J. Phys. Chem. Lett. 4 (2013) 1821-1828.

[10] K.C. Kao, Dielectric Phenomena in Solids: with Emphasis on Physical Concepts of Electronic Processes, Elsevier Academic Press, Boston, 2004.

[11] S.K. Bhattacharya, R.R. Tummala, Next generation integral passives: Materials, processes, and integration of resistors and capacitors on PWB substrates, J. Mater. Sci.: Mater. Elect. 11 (2000) 253-268.

[12] M. Engel, D. Schaefer, D. Erni, N. Benson, R. Schmechel, Reduced Coulomb interaction in organic solar cells by the introduction of inorganic high-k nanostructured materials, Phys. Status Solidi A 210 (2013) 1712-1718.

[13] H. Choi, J.P. Lee, S.J. Ko, J.W. Jung, H. Park, S. Yoo, O. Park, J.R. Jeong, S. Park, J.Y. Kim, Multipositional silica-coated silver nanoparticles for high-performance polymer solar cells, Nano Lett. 13 (2013) 2204-2208.

[14] Y. Yuan, T.J. Reece, P. Sharma, S. Poddar, S. Ducharme, A. Gruverman, Y. Yang, J. Huang, Efficiency enhancement in organic solar cells with ferroelectric polymers, Nat. Mater. 10 (2011) 296-302.

[15] Z. Xiao, Q. Dong, P. Sharma, Y. Yuan, B. Mao, W. Tian, A. Gruverman, J. Huang, Synthesis and application of ferroelectric $\mathrm{P}(\mathrm{VDF}-\mathrm{TrFE})$ nanoparticles in organic photovoltaic devices for high efficiency, Adv. Energy Mater. 3 (2013) 1581-1588.

[16] P. Saini, Fundamentals of Conjugated Polymer Blends, Copolymers and Composites: 
Synthesis, Properties and Applications, Wiley, Hoboken, NJ, 2015.

[17] S. Torabi, F. Jahani, I. Van Severen, C. Kanimozhi, S. Patil, R.W.A. Havenith, R.C. Chiechi, L. Lutsen, D.J.M. Vanderzande, T.J. Cleij, J.C. Hummelen, L.J.A. Koster, Strategy for enhancing the dielectric constant of organic semiconductors without sacrificing charge carrier mobility and solubility, Adv. Funct. Mater. 25 (2015) 150-157.

[18] F. Jahani, S. Torabi, R.C. Chiechi, L.J.A. Koster, J.C. Hummelen, Fullerene derivatives with increased dielectric constants, Chem. Commun. 50 (2014) 10645-10647.

[19] C. Duan, K. Zhang, X. Guan, C. Zhong, H. Xie, F. Huang, J. Chen, J. Peng, Y. Cao, Conjugated zwitterionic polyelectrolyte-based interface modification materials for high performance polymer optoelectronic devices, Chem. Sci. 4 (2013) 1298-1307.

[20] F. Liu, Z.A. Page, V.V. Duzhko, T.P. Russell, T. Emrick, Conjugated polymeric zwitterions as efficient interlayers in organic solar cells, Adv. Mater. 25 (2013) 6868-6873.

[21] Z.A. Page, Y. Liu, V.V. Duzhko, T.P. Russell, T. Emrick, Fulleropyrrolidine interlayers: Tailoring electrodes to raise organic solar cell efficiency, Science 346 (2014) 441-444.

[22] X. Liu, K.S. Jeong, B.P. Williams, K. Valchshouri, C. Guo, K. Han, E.D. Gomez, Q. Wang, J.B. Asbury, Tuning the dielectric properties of organic semiconductors via salt doping, J. Phys. Chem. B 117 (2013) 15866-15874.

[23] N. Cho, C.W. Schlenker, K.M. Knesting, P. Koelsch, H.L. Yip, D.S. Ginger, A.K.Y. Jen, High-dielectric constant side-chain polymers show reduced non-geminate recombination 
in heterojunction solar cells, Adv. Energy Mater. 4 (2014) 1301857-1301862.

[24] P. Yang, M. Yuan, D.F. Zeigler, S.E. Watkins, J.A. Lee, C.K. Luscombe, Influence of fluorine substituents on the film dielectric constant and open-circuit voltage in organic photovoltaics, J. Mater. Chem. C 2 (2014) 3278-3284.

[25] H.D. de Gier, R. Broer, R.W.A. Havenith, Non-innocent side-chains with dipole moments in organic solar cells improve charge separation, Phys. Chem. Chem. Phys. 16 (2014) 12454-12461.

[26] T. Fukasawa, T. Sato, J. Watanabe, Y. Hama, W. Kunz, R. Buchner, Relation between dielectric and low-frequency Raman spectra of hydrogen-bond liquids, Phys. Rev. Lett. $95(2005) 197802$.

[27] V. Sharma, C. Wang, R.G. Lorenzini, R. Ma, Q. Zhu, D.W. Sinkovits, G. Pilania, A.R. Oganov, S. Kumar, G.A. Sotzing, S.A. Boggs, R. Ramprasad, Rational design of all organic polymer dielectrics, Nat. Commun. 5 (2014) 4845.

[28] R. Singh, R.K. Singh, J. Kumar, R. Kant, V. Kumar, The origin of DC electrical conduction and dielectric relaxation in pristine and doped poly(3-hexylthiophene) films, J. Polym. Sci., Part B: Polym. Phys. 48 (2010) 1047-1053.

[29] F. Yakuphanoglu, M. Sekerci, E. Evin, The determination of the conduction mechanism and optical band gap of fluorescein sodium salt, Physica B 382 (2006) 21-25.

[30] S.A. Mansour, I.S. Yahia, G.B. Sakr, Electrical conductivity and dielectric relaxation behavior of fluorescein sodium salt (FSS), Solid State Commun. 150 (2010) 1386-1391. 
[31] Z. Mao, W. Senevirathna, J.-Y. Liao, J. Gu, S.V. Kesava, C. Guo, E.D. Gomez, G. Sauve, Azadipyrromethene-based $\mathrm{Zn}$ (II) complexes as nonplanar conjugated electron acceptors for organic photovoltaics, Adv. Mater. 26 (2014) 6290-6294.

[32] M. Lammens, J. Skey, S. Wallyn, R.K. O'Reilly, F. Du Prez, Polymeric ligands as homogeneous, reusable catalyst systems for copper assisted click chemistry, Chem. Commun. 46 (2010) 8719-8721.

[33] H.C. Kolb, M.G. Finn, K.B. Sharpless, Click chemistry: Diverse chemical function from a few good reactions, Angew. Chem. Int. Ed. 40 (2001) 2004-2021.

[34] H.A.S. Al-Shamiri, M.T.H. Abou Kana, I.M. Azzouz, A.H.M. Elwahy, Photo-physical properties and amplified spontaneous emission of a new derivative of fluorescein, Opt. Commun. 283 (2010) 1438-1444.

[35] J. Miao, L. Zhu, Hydrogen bond-assisted supramolecular self-assembly of doubly discotic supermolecules based on porphyrin and triphenylene, Chem. Mater. 22 (2010) 197-206.

[36] J. Miao, L. Zhu, Columnar liquid crystalline assembly of doubly discotic supermolecules based on tetra-triphenylene-substituted phthalocyanine, Soft Matter 6 (2010) 2072-2079.

[37] G. Giri, E. Verploegen, S.C.B. Mannsfeld, S. Atahan-Evrenk, D.H. Kim, S.Y. Lee, H.A. Becerril, A. Aspuru-Guzik, M.F. Toney, Z. Bao, Tuning charge transport in solution-sheared organic semiconductors using lattice strain, Nature 480 (2011) 504-U124. 
[38] R.I. Gearba, M. Lehmann, J. Levin, D.A. Ivanov, M.H.J. Koch, J. Barbera, M.G. Debije, J. Piris, Y.H. Geerts, Tailoring discotic mesophases: Columnar order enforced with hydrogen bonds, Adv. Mater. 15 (2003) 1614-1618.

[39] J. Wei, Z. Zhang, J.-K. Tseng, I. Treufeld, X. Liu, M.H. Litt, L. Zhu, Achieving high dielectric constant and low loss property in a dipolar glass polymer containing strongly dipolar and small-sized sulfone groups, ACS Appl. Mater. Interfaces 7 (2015) 5248-5257.

[40] A.R. Katritzky, C.W. Rees, E.F.V. Scriven, Comprehensive heterocyclic chemistry II: A review of the literature 1982-1995: the structure, reactions, synthesis, and uses of heterocyclic compounds, 1st ed., Pergamon, New York, 1996.

[41] J. Melcher, Y. Daben, G. Arlt, Dielectric effects of moisture in polyimide, IEEE Trans. Electr. Insul. 24 (1989) 31-38.

[42] R.E. Dinnebier, M. Pink, J. Sieler, P.W. Stephens, Novel alkali-metal coordination in phenoxides: Powder diffraction results on $\mathrm{C}_{6} \mathrm{H}_{5} \mathrm{OM}(\mathrm{M}=\mathrm{Li}, \mathrm{Na}, \mathrm{K}, \mathrm{Rb}, \mathrm{Cs})$, Inorg. Chem. 36 (1997) 3398-3401.

[43] M.E. Fraser, S. Fortier, M.K. Markiewicz, A. Rodrigue, J.W. Bovenkamp, The crystal-structures of the 1-1-1 complexes of dicyclohexano-18-crown-6 (isomer-B) with potassium phenoxide and phenol and dicyclohexano-18-crown-6 (isomer-A) with sodium phenoxide and phenol, Can. J. Chem. 65 (1987) 2558-2563.

[44] D. Margulies, G. Melman, A. Shanzer, Fluorescein as a model molecular calculator with 
reset capability, Nat. Mater. 4 (2005) 768-771.

[45] R. Steyrleuthner, M. Schubert, F. Jaiser, J.C. Blakesley, Z. Chen, A. Facchetti, D. Neher, Bulk electron transport and charge injection in a high mobility $n$-type semiconducting polymer, Adv. Mater. 22 (2010) 2799-803. 